\title{
A Clinically Diagnosed Congenital Rubella Syndrome and Congenital Cytomegalovirus Co-infection
}

\author{
Roland Joseph D. Tan, MD, MS,1,2 Darby E. Santiago, MD ${ }^{1,2}$ and Yasser E. Alhasan, MD ${ }^{1}$ \\ ${ }^{1}$ Department of Ophthalmology, Baguio General Hospital and Medical Center, Baguio City, Philippines \\ ${ }^{2}$ Department of Ophthalmology Visual Sciences, College of Medicine and Philippine General Hospital, University of the Philippines Manila
}

\begin{abstract}
This is a case of a four-month-old female infant who presented with clinical manifestations of congenital rubella syndrome (CRS) - bilateral cataracts, poorly-dilating pupils, microcorneas, salt and pepper retinopathies seen after cataract extractions, bilateral sensorineural hearing loss, patent ductus arteriosus, microcephaly, history of blueberry spots and low birth weight, and positive serum IgM and IgG tests for rubella. The patient's mother also had prenatal rubella infection. However, the patient also presented with additional set of clinical findings not seen in recent patients with CRS and not commonly reported in literature: visual acuities of poor to no dazzle, bilateral choroidal thickening on ocular ultrasound that spontaneously resolved, optic nerve inflammation that became atrophic, vessel tortuosities seen after cataract extractions, bilateral subependymal cysts with lenticulostriate vasculopathy in basal ganglia, basal ganglia hyperintensity suggestive of calcification, and jaundice. These findings plus the overlapping clinical manifestations with CRS and the positive IgM and IgG for cytomegalovirus (CMV) made us consider a congenital CMV co-infection.
\end{abstract}

CRS already causes significant childhood morbidity. Getting co-infected with CMV in utero worsens morbidity and makes management more difficult. This case presented a congenital co-infection of rubella and CMV and discussed the added challenges in their diagnosis and management.

Keywords: congenital rubella syndrome, congenital CMV infection, co-infection, congenital, Philippines

\section{INTRODUCTION}

Toxoplasma, rubella, cytomegalovirus (CMV), herpes simplex virus (ToRCH) co-infection has been reported in six pregnant women in India, with one being seropositive for CMV and rubella. ${ }^{1}$ Maternal ToRCH co-infection has been associated with increased risk of abortion. ${ }^{2,3}$ However, $\mathrm{IgG}$ antibodies against more than one of the ToRCH diseases were found among 0 - to 6-month-old infants in Qatar. ${ }^{4}$ It was not mentioned if the infants were congenitally co-infected nor their clinical manifestations described. Differentiating between the ToRCH infections may prove challenging in the absence of or costly serological tests due to overlap in clinical presentation; in the absence of costly serological tests; however, this is necessary for appropriate management.

Congenital rubella syndrome (CRS) has been estimated to be present in 105,000 infants globally every year from 1996-2010.5 Diagnosis of CRS requires the detection of $\mathrm{IgG}$ antibodies using enzyme-linked immunosorbent assay (ELISA) in the serum of the affected infant and collected in

Corresponding author: Roland Joseph D. Tan, MD, MS Department of Ophthalmology Baguio General Hospital and Medical Center, Baguio City, Philippines Email: rdtan@up.edu.ph the first three months of life. Confirmation can be done with detection of rubella using PCR in nasopharyngeal swabs, oral swabs or urine. ${ }^{6}$ Ophthalmological presentations of CRS include cataract, pigmentary retinopathy, microphthalmos 
and chorioretinitis (Table 1). ${ }^{7}$ There is no cure for CRS but its clinical manifestations such as cataract and cardiac anomalies are treatable. ${ }^{7}$

CMV is the leading cause of congenital anomalies due to prenatal infection. It globally affects 1 in 150 live births. ${ }^{10}$ However, only 5 to $15 \%$ of those infected becomes symptomatic. ${ }^{11}$ Diagnosis of congenital CMV (cCMV) infection requires the detection of CMV using polymerase chain reaction (PCR) in the saliva or urine of the infant collected on the first 3 weeks of life. ${ }^{12}$ Ophthalmological presentation of cCMV infection also include chorioretinitis but with major retinal vascular occlusions and arterio-venous anastomosis, pigmentary retinopathy, optic atrophy, strabismus, cortical visual impairment and poor vision. ${ }^{11,13-17}$ Optic neuritis or papillitis were reported among immunodeficient individuals with CMV. Other systemic manifestations of cCMV infection are listed in Table 2. The current treatment recommended for symptomatic cCMV is oral ganciclovir $16 \mathrm{mg} / \mathrm{kg}$ body weight two times a day for six months which resulted in better neurological and hearing outcomes long term. ${ }^{18,19}$ A newborn with chorioretinitis was successfully treated with the addition of intravitreal ganciclovir and foscarnet. ${ }^{20}$ Another infant had retinitis from cCMV at 5 months of age, which spontaneously resolved without treatment. ${ }^{18}$

There has been no case report describing the clinical manifestations of congenital co-infection of CMV and rubella locally and internationally.

\section{CASE PRESENTATION}

This is the case of a four-month-old female infant referred to the Ophthalmology Service for bilateral cataracts. She was born full term with a birthweight of $1.8 \mathrm{~kg}$ to a

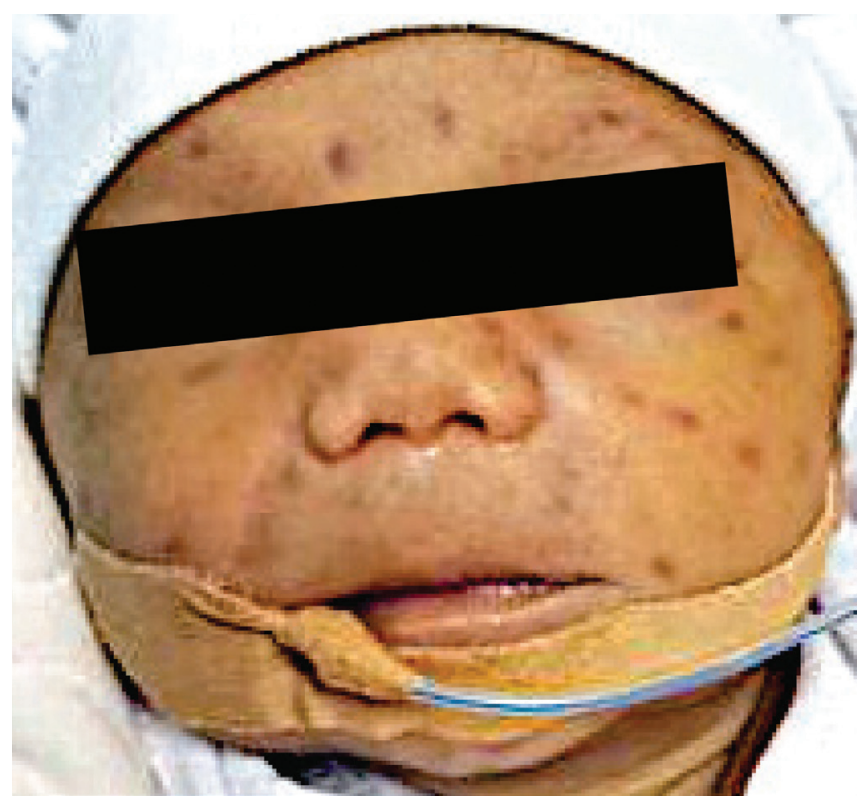

Figure 1. Multiple petechiae or blueberry spots in the face.

G2P2 (2002) 28-year-old mother. She had meconium staining at birth and was admitted in the neonatal ICU for neonatal pneumonia. She was jaundiced and had multiple petechiae that time described as blueberry spots which eventually resolved (Figure 1). She also had cataracts on both eyes; thus, the referral.

It was elicited that cataract were noted at birth and that mother had history of rubella infection described as generalized rashes and fever for a day during the first month of pregnancy. There was an inconsistent dazzle on both eyes with no relative afferent pupillary defect. A visual evoked potential test could not be done due to the test's local

Table 1. Summary of clinical presentations of congenital rubella syndrome

\section{Shukla and Marakha ${ }^{7}$}

Eye Unilateral or bilateral cataract, chorioretinitis, salt and pepper

retinopathy, and microphthalmos

\section{Vijayalakshmi et al. ${ }^{8}$}

Anophthalmia, rigid pupil, cloudy Retinopathy (55\%) or opacified cornea, micro- Cataract (27\%) cornea, hypoplastic iris, atropic optic nerve and glaucoma

\begin{tabular}{|c|c|c|c|}
\hline $\begin{array}{l}\text { Ear, Nose } \\
\text { and Mouth }\end{array}$ & Sensorineural hearing loss & - & $\begin{array}{l}\text { Impaired hearing or deafness } \\
(95 \%)\end{array}$ \\
\hline Cardiac & $\begin{array}{l}\text { Atrial septal defects, ventricular septal defects, peripheral } \\
\text { pulmonary artery stenosis and patent ductus arteriosus }\end{array}$ & - & Cardiac defects (32\%) \\
\hline Neurological & $\begin{array}{l}\text { Mental retardation, behavioral disorders, microcephaly, } \\
\text { calcifications in the cerebrum and meningoencephalitis }\end{array}$ & - & Mental retardation (45\%) \\
\hline Hematologic & $\begin{array}{l}\text { Purpura, petechiae, "blueberry muffin" indicative of dermal } \\
\text { erythropoiesis, rash thrombocytopenia and hemolytic anemia }\end{array}$ & - & - \\
\hline Orthopedic & Metaphysis of long bones become radiolucent, "celery stalking" & - & - \\
\hline Abdominal & Enlargement of liver and spleen, & - & - \\
\hline Endocrine & - & - & Diabetes and hypothyroidism \\
\hline Perinatal & Low birth weight & - & - \\
\hline Others & Interstitial pneumonitis, diabetes mellitus and thyroid disease & - & $\begin{array}{l}\text { Deficiency in growth hormone } \\
\text { and Addison's disease }\end{array}$ \\
\hline
\end{tabular}


Table 2. Summary of clinical presentations of congenital CMV infection

\begin{tabular}{|c|c|c|c|c|c|c|c|}
\hline & Ghekiere et al. ${ }^{11}$ & Gantt et al. ${ }^{12}$ & Tagami et al. ${ }^{13}$ & $\begin{array}{l}\text { Anderson } \\
\text { et al. }{ }^{14}\end{array}$ & Jin et al. ${ }^{16}$ & Jin et al. ${ }^{17}$ & Leung et al. ${ }^{21}$ \\
\hline Eye & $\begin{array}{l}\text { Corneal scarring, } \\
\text { anterior polar } \\
\text { cataract, chorio- } \\
\text { retinitis +/- hemorr- } \\
\text { hages, scarring in the } \\
\text { macula and retinal } \\
\text { periphery, optic nerve } \\
\text { atrophy/ hypoplasia/ } \\
\text { coloboma, cortical } \\
\text { visual impairment } \\
\text { (VI) strabismus, } \\
\text { microphthalmia, } \\
\text { anophthalmia and } \\
\text { incomplete cyclopia }\end{array}$ & $\begin{array}{l}\text { Chorioretinitis, } \\
\text { scarring of the } \\
\text { retina and optic } \\
\text { nerve atrophy }\end{array}$ & $\begin{array}{l}\text { Occlusion of } \\
\text { retinal vessels } \\
\text { and arterio- } \\
\text { venous } \\
\text { anastomosis }\end{array}$ & $\begin{array}{l}\text { Chorioretinitis, } \\
\text { pigmentary } \\
\text { retinopathy, } \\
\text { optic atrophy } \\
\text { and strabismus }\end{array}$ & $\begin{array}{l}\text { Chorioretinitis, } \\
\text { scarring of } \\
\text { the retina, } \\
\text { optic atrophy, } \\
\text { cortical VI and } \\
\text { strabismus }\end{array}$ & $\begin{array}{l}\text { Anterior } \\
\text { segment } \\
\text { changes, } \\
\text { cortical VI, } \\
\text { strabismus } \\
\text { amblyopia } \\
\text { and } \\
\text { nystagmus }\end{array}$ & Chorioretinitis \\
\hline $\begin{array}{l}\text { Ear, Nose } \\
\text { and Mouth }\end{array}$ & $\begin{array}{l}\text { Sensorineural } \\
\text { hearing loss }\end{array}$ & $\begin{array}{l}\text { Sensorineural } \\
\text { hearing loss }\end{array}$ & - & - & $\begin{array}{l}\text { Sensorineural } \\
\text { hearing loss }\end{array}$ & $\begin{array}{l}\text { Sensorineural } \\
\text { hearing loss }\end{array}$ & $\begin{array}{l}\text { High arch } \\
\text { palate, defective } \\
\text { enamelization } \\
\text { of teeth }\end{array}$ \\
\hline Neurological & $\begin{array}{l}\text { Abnormalities of } \\
\text { the white matter, } \\
\text { malformation and } \\
\text { calcifications of } \\
\text { cortex, enlargement } \\
\text { of ventricles, } \\
\text { dysplasia of } \\
\text { hippocampus, } \\
\text { microcephaly neuro- } \\
\text { developmental delay, } \\
\text { mental retardation, } \\
\text { motor disabilities }\end{array}$ & $\begin{array}{l}\text { Atrophy and } \\
\text { calcifications of } \\
\text { cortex, polymicro- } \\
\text { gyria, lisencephaly, } \\
\text { enlargement of } \\
\text { ventricles periventri- } \\
\text { cular cysts, lenticulos- } \\
\text { triate vasculopathy, } \\
\text { hypoplasia of cere- } \\
\text { bellum, seizures, } \\
\text { microcephaly lethargy } \\
\text { and hypotonia }\end{array}$ & - & - & $\begin{array}{l}\text { Calcification } \\
\text { of cortex, } \\
\text { enlargement } \\
\text { of ventricles, } \\
\text { encephalo- } \\
\text { malacia, } \\
\text { microcephaly } \\
\text { and seizure }\end{array}$ & $\begin{array}{l}\text { Cranial CT } \\
\text { abnormalities, } \\
\text { and } \\
\text { microcephaly }\end{array}$ & $\begin{array}{l}\text { Hypotonia, } \\
\text { lethargy, } \\
\text { microcephaly, } \\
\text { enlargement } \\
\text { of ventricles, } \\
\text { calcification } \\
\text { intracranially, } \\
\text { hydrocephalus, } \\
\text { intracranial } \\
\text { hemorrhage }\end{array}$ \\
\hline Hematologic & $\begin{array}{l}\text { Rashes, petechiae, } \\
\text { thrombocytopenia, } \\
\text { neonatal jaundice, }\end{array}$ & $\begin{array}{l}\text { Purpura, petechiae, } \\
\text { thrombocytopenia, } \\
\text { neonatal jaundice, } \\
\text { conjugated hyper- } \\
\text { bilirubinemia }\end{array}$ & - & - & - & - & $\begin{array}{l}\text { Jaundice (62\%), } \\
\text { petechiae (52\%), } \\
\text { Blueberry spots }\end{array}$ \\
\hline Abdominal & Hepatosplenomegaly & $\begin{array}{l}\text { Hepatosplenomegaly, } \\
\text { hepatitis, poor } \\
\text { feeding }\end{array}$ & - & - & - & - & $\begin{array}{l}\text { Hepatospleno- } \\
\text { megaly (50\%), } \\
\text { fetal ascites, poor } \\
\text { feeding, hepatitis }\end{array}$ \\
\hline Perinatal & IUGR & $\begin{array}{l}\text { IUGR, hydrops fetalis, } \\
\text { calcifications in the } \\
\text { viscera, enlargement } \\
\text { of placenta, hyper- } \\
\text { echogenic intestines } \\
\text { and small for } \\
\text { gestational age }\end{array}$ & - & - & - & - & $\begin{array}{l}\text { Prematurity, } \\
\text { polyhydramnios, } \\
\text { Oligohydramnios, } \\
\text { non-immune } \\
\text { hydrops, IUGR }\end{array}$ \\
\hline Others & Pneumonia & $\begin{array}{l}\text { Pneumonitis and } \\
\text { primary immuno- } \\
\text { deficiency }\end{array}$ & - & - & - & - & $\begin{array}{l}\text { Clasp thumb, } \\
\text { clubfoot, inguinal } \\
\text { hernia, pneu- } \\
\text { monia, osteitis }\end{array}$ \\
\hline
\end{tabular}

IUGR, Intrauterine growth retardation

unavailability and inaccessibility due to the pandemic. Her sclerae were icteric. Gross examination showed bilateral cataracts and ocular ultrasound revealed thickened choroid in both eyes, which indicated choroiditis (Figure 2). The vitreous was clear and retina were attached on both eyes.

Although a preliminary diagnosis of CRS was made based on maternal infection and bilateral cataracts, another condition was being considered due to the poor vision, thickened choroids and presence of jaundice, which were not seen in the recent three cases of CRS in this institution. She became tachypneic, was admitted and revealed to have a 2.5 to $2.75 \mathrm{~mm}$ patent ductus arteriosus with left-to-right shunting on 2D echocardiography, and pulmonary artery hypertension. She was started on sildenafil $50 \mathrm{mg}$ tablet 4 
times a day. She was further assessed as stunted and wasted. She was still jaundiced and her stool was acholic. Her direct, indirect and total serum bilirubin levels were elevated at $82 \mu \mathrm{mol} / \mathrm{L}, 96 \mathrm{~mol} / \mathrm{L}$ and $177 \mu \mathrm{mol} / \mathrm{L}$, respectively. Aspartate aminotransferase, alanine aminotranferase and gamma-glutamyl transferase were all elevated at $126 \mathrm{U} / \mathrm{L}$, $101 \mathrm{U} / \mathrm{L}$ and $429 \mathrm{U} / \mathrm{L}$, respectively. The liver, gallbladder, pancreas, spleen, kidneys and urinary bladder were all normal on abdominal ultrasound. A liver biopsy revealed acute and chronic non-specific hepatitis with periportal fibrosis, ballooning degeneration and bile stasis (Figure 3). Although the biochemical profile of the patient points to a cholestatic type of hepatitis that leads to biliary cirrhosis, the usual finding of a direct hyperbilirubinemia in patients with hepatocellular jaundice may have been overwhelmed

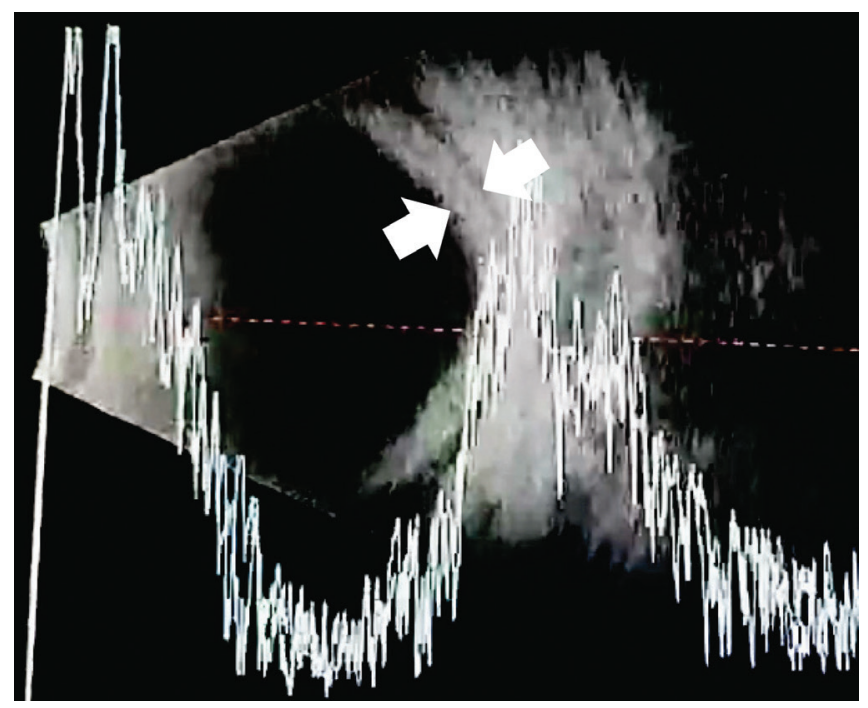

Figure 2. Ocular ultrasound of the left eye which shows thickened choroid (in between the two white arrows) suggestive of inflammation.

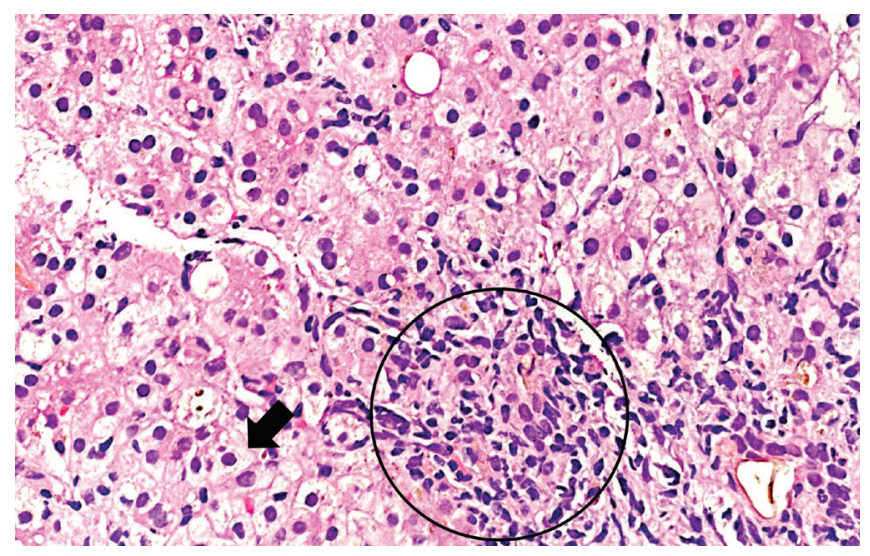

Figure 3. There is presence of monolobulated and multilobulated cells (black circle) surrounding the hepatocytes suggestive of acute and chronic hepatitis. There is also ballooning of hepatocytes (black arrow). by resultant portal hypertension causing hypersplenism and possible peripheral hemolysis in the spleen, resulting in a mixed hyperbilirubinemia.

The patient was microcephalic. Cranial ultrasound revealed bilateral subependymal cyst with lenticulostriate vasculopathy in bilateral basal ganglia while cranial CT revealed hyperdense basal ganglia probably due to calcifications. Auditory testing revealed congenital hearing loss on both ears. The patient underwent cataract surgery for the left eye despite parents being told of poor visual prognosis. Intraoperative examination revealed small corneal diameters (8 $\mathrm{mm}$ vertically and $10 \mathrm{~mm}$ horizontally) and poorly dilating pupils in both eyes. On fundoscopy, a membranelike structure over the superior and inferior arcuate, slightly pale retina and papillitis were seen. A fundus photo was not retrieved due to the poorly dilating pupil and absence of a portable fundus camera. Her ToRCH test came back positive for rubella and cytomegalovirus IgG and IgM. The patient was then referred to a national center for testing of CMV in urine and possible systemic antiviral treatment.

Due to financial constraints and the ongoing COVID-19 pandemic, the patient was not able to consult in the national center. Instead, they consulted back with us after two months since the mother claimed that the patient started having a consistent dazzle in the unoperated right eye. The visual acuity of poor dazzle in the left eye remained. On follow up, patient was no longer jaundiced and was discontinued on sildenafil. There was a consistent dazzle on the right eye. Repeat ocular ultrasound revealed resolution of the choroidal thickening on both eyes (Figure 4).

The patient then underwent cataract surgery for the right eye, and similar to the left eye, the pupil was poorly dilating that iris hooks were used to retract it (Figure 5).

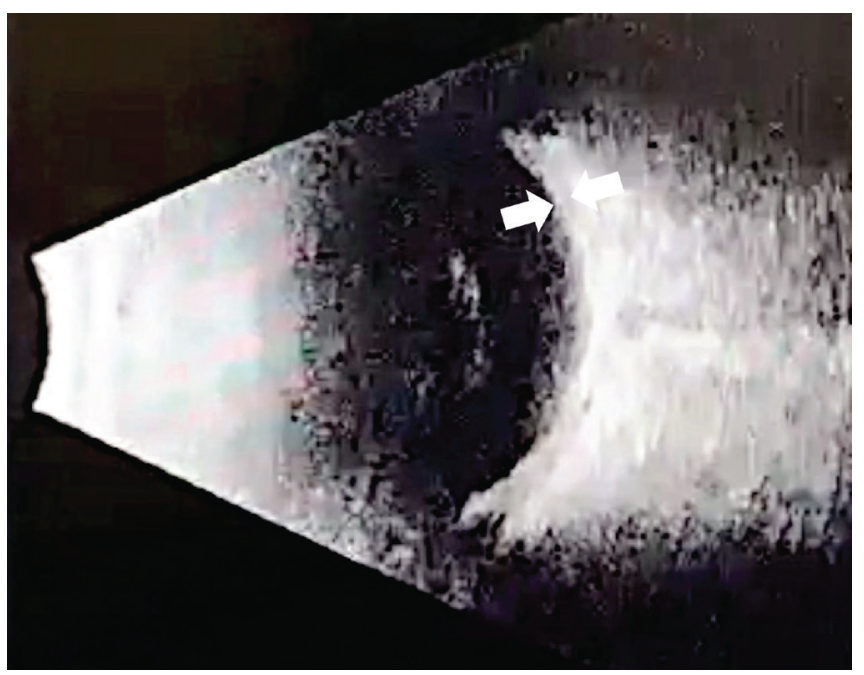

Figure 4. Ocular ultrasound of the left eye, which shows regular choroid (between white arrows) indicating resolution of previous choroid inflammation. 
On fundoscopy, the left eye had a red-orange optic nerve with slightly tortuous vessels and slightly pale retina (Figure 6) with salt-and-pepper appearance. Repeat fundoscopy of the right eye revealed a posterior vitreous detachment, pale optic nerve, tortuous vessels and pale retina (Figure 7) with salt and pepper appearance. The patient is still for urine CMV PCR and for future secondary intraocular lens (IOL) implantation.

\section{DISCUSSION}

The patient was clinically diagnosed with CRS based on clinical presentation, history of maternal rubella and the ToRCH titer results. A congenital CMV co-infection was considered based on the other clinical findings, overlapping presentation with CRS such as sensorineural hearing loss,

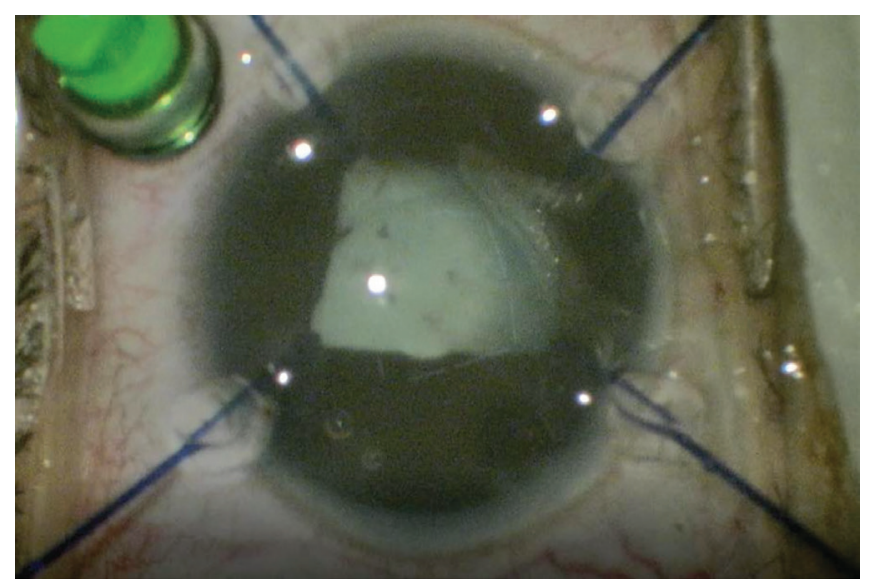

Figure 5. A poorly-dilating pupil of the right eye during cataract surgery with iris hooks (blue lines) in place to retract the pupil.

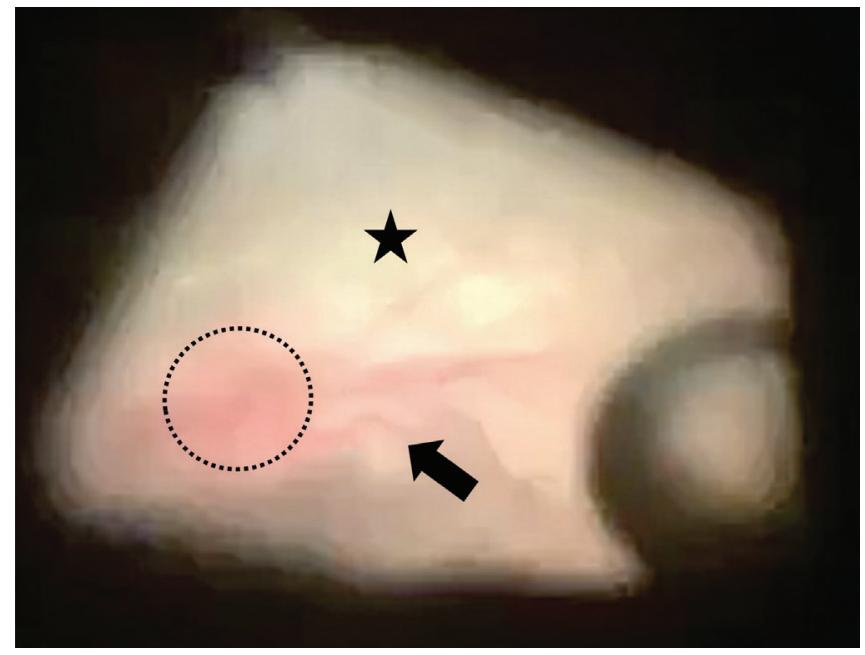

Figure 6. Fundoscopy of the right eye showed a red-orange optic nerve (dotted circle) with slightly tortuous vessels (black arrow) and slightly pale retina (star). microcephaly and blueberry spots and the ToRCH titer results. The detection of both viruses using PCR from specimens collected at three weeks and three months of life required in their diagnosis were not done since we received the patient after said periods and both managing institutions did not have the capability to perform said tests. ${ }^{12,22}$ However, the presence of congenital anomalies found and reported in literature from laboratory-confirmed cases of CRS and cCMV (as oppose to postnatal infections) in our patient (Table 3) made us consider that both CMV and rubella were acquired prenatally and that congenital coinfection can exist. With this case report, ophthalmologists and pediatricians can be better informed in the diagnosis and management of this set of patients.

Rubella cataracts have been and continue to be a significant cause of pediatric visual impairment in the Philippines. ${ }^{23}$ Although these cases can be treated with surgery, optical correction and visual rehabilitation, longterm management of rubella cataract alone is already challenging. Intraocular lens (IOL) implantation, which can offer the cheapest and optimal option for optical correction, is preferably delayed to lessen inflammation that may result in complications such as membrane formation that can cover the visual axis. ${ }^{24}$ Delaying the IOL implantation will require another surgery in the future. Aphakic spectacles are used while awaiting the ideal time for secondary IOL implantation. The added surgery, multiple follow ups and the need to regularly change expensive high-power aphakic spectacles add cost to the management challenge. This is in

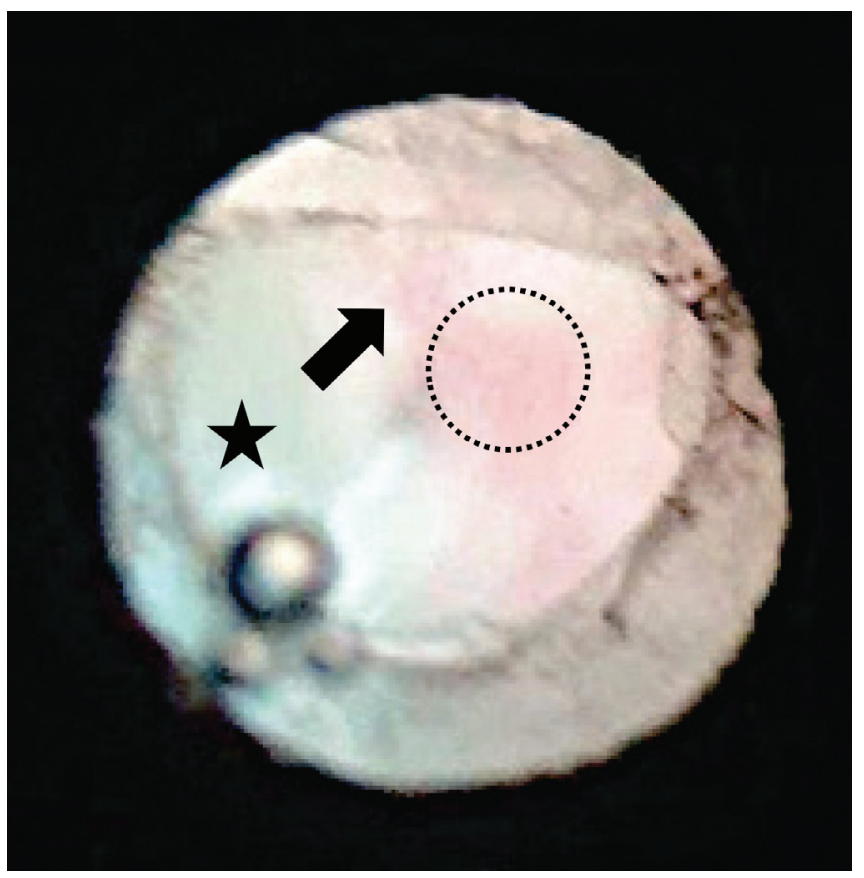

Figure 7. Fundoscopy of the left eye showed a pale optic nerve (dotted circle) with slightly tortuous vessels (black arrow) and pale retina (star). 
Table 3. Summary of the clinical presentation of the patient clinically diagnosed with congenital rubella syndrome and congenital cytomegalovirus

\begin{tabular}{ll}
\hline Eye & Bilateral cataracts (R) \\
& Poorly-dilating pupils (R) \\
& Salt and pepper retinopathies (R) \\
& Spontaneous resolved choroidal thickening (C) \\
& Tortuous vessels (C) \\
& Papillitis (C) \\
& Atrophic optic nerve (B) \\
& Microcorneas (R) \\
& Pale retina (B) \\
\hline Ear, Nose and Mouth & Sensorineural hearing loss (B) \\
\hline Cardiac & Patent ductus arteriosus (R) \\
& Pulmonary hypertension (R) \\
\hline Neurological & Subependymal cysts (C) \\
& Lenticulostriate vasculopathy (C) \\
& Basal ganglia hyperdensity (B) \\
& Microcephaly (B) \\
\hline Hematologic & Petechiae, blueberry spots (B) \\
\hline Abdominal & Jaundice (C) \\
\hline Perinatal & Hepatitis (C) \\
\hline R & Low birth weight (R)
\end{tabular}

$R$ - Rubella, C - Cytomegalovirus, B - Both

addition to the cost accrued from often expensive treatments for the patient's cardiac anomalies. There is also the anesthetic concern since some CRS patients are underweight and have coexisting comorbidities in addition to hospital logistical concerns since CRS patients less than one year of age are still deemed infectious and need to be isolated. ${ }^{25,26}$

The rubella virus is known to primarily affect epithelial cells including the retinal pigment epithelium, which may explain the salt-and-pepper appearance. ${ }^{27}$ Although optic nerve atrophy and choroidal neovascularization have been reported, CRS usually does not affect visual acuity. ${ }^{8,28}$ This was the first among four recent CRS cases seen by the primary author with poor vision. Thus, cCMV was considered, which may have played a role in the spontaneously resolving choroidal thickening and the poor vision on the left eye. This, together with the other systemic findings associated with cCMV, made the management more challenging for this case. The patient is still for urine CMV PCR to determine if there is still a need for systemic antiviral treatment. ${ }^{19}$ The high cost of ganciclovir and its extended use for six months, if indicated, are an added financial challenge to the already costly management of the patient.

The patient should have regular follow up with an audiologist to monitor response to antiviral treatment, if started, or to determine the need for an electronic hearing device. ${ }^{29}$ Developmental and learning disabilities should be monitored and addressed. Since infants with CRS are considered contagious up to one year of age unless proven otherwise, and infants with cCMV can shed the virus in saliva and urine, isolation and hand hygiene are highly recommended. ${ }^{7}$ It is important to emphasize the need for women of reproductive age or those planning to conceive to have ToRCH testing, despite status of rubella vaccination, to determine if their rubella antibody levels are protective.

\section{CONCLUSION}

This case presented the congenital co-infection of rubella and CMV and the added challenges in its diagnosis and management.

\section{Statement of Authorship}

All authors participated in the data collection and analysis and approved the final version submitted.

\section{Author Disclosure}

All authors declared no conflicts of interest.

\section{Funding Source}

No funding support.

\section{REFERENCES}

1. Rajani M. Serological profile of TORCH Infection among antenatal women at a tertiary care center in North India. J Pure Appl Microbiol. 2018; 12(4):2305-11.

2. Rasti S, Ghasemi F, Abdoli A, Piroozmand A, Mousavi S, FakhrieKashan Z. ToRCH "co-infections" are associated with increased risk of abortion in pregnant women. Congenit Anomalies. 2016; 56(2): 73-8.

3. Wang Y, Li S, Ma N, Zhang Q, Wang H, Cui J et al. The association of ToRCH infection and congenital malformations: A prospective study in China. Eur J Obstet Gynecol Reprod Biol. 2019 Sep; 240: 336-40. doi: 10.1016/j.ejogrb.2019.04.042.

4. Abu-Madi M, Behnke J, Dabritz H. Toxoplasma gondii seropositivity and co-infection with TORCH pathogens in high-risk patients from Qatar. Am J Trop Med Hyg. 2010; 82(4):626-33.

5. Vynnycky E, Adams EJ, Cutts FT, Reef SE, Navar AM, Simons E et al. Using seroprevalence and immunisation coverage data to estimate the global burden of congenital rubella syndrome, 1996-2010: a systematic review. PLoS One. 2016; 11:e0149160.

6. Bouthry E, Picone O, Hamdi G, Grangeot-Keros L, Ayoubi J, Vauloup-Fellous C. Rubella and pregnancy: diagnosis, management and outcomes. Prenat Diagn. 2014; 34(13):1246-53.

7. Shukla S, Maraqa NF. Congenital Rubella. In: StatPearls [Internet]. Treasure Island, FLorida: StatPearls Publishing; 2021 [cited 2006 Jan] Available from: https://www.ncbi.nlm.nih.gov/books/NBK507879/

8. Vijayalakshmi P, Rajasundari T, Prasad N, Prakash S, Narendran $\mathrm{K}$, Ravindran $\mathrm{M}$ et al. Prevalence of eye signs in congenital rubella syndrome in South India: A role for population screening. Br J Ophthalmol. 2007; 91(11):1467-70.

9. Viskari H, Paronen J, Keskinen P, Simell S, Zawilinska B, ZgorniakNowosielska I et al. Humoral $\beta$-cell autoimmunity is rare in patients with the congenital rubella syndrome. Clin Exp Immunol. 2003; 133(3):378-83.

10. Permar S, Schleiss M, Plotkin S. Advancing our understanding of protective maternal immunity as a guide for development of vaccines to reduce congenital cytomegalovirus infections. J Virol. 2018; 92(7).

11. Ghekiere S, Allegaert K, Cossey V, Van Ranst M, Cassiman C, Casteels I. Ophthalmological findings in congenital cytomegalovirus infection: when to screen, when to treat?. J Pediatr Ophthalmol Strabismus. 2012; 49(5):274-82. 
12. Gantt S, Bitnun A, Renaud C, Kakkar F, Vaudry W. Diagnosis and management of infants with congenital cytomegalovirus infection. Paediatr Child Health. 2017; 22(2):72-4.

13. Tagami M, Honda S, Morioka I, Iijima K, Yamada H, Nakamura M. An unusual case of congenital cytomegalovirus infection-related retinopathy. BMC Ophthalmol. 2016; 16(1).

14. Anderson KS, Amos CS, Boppana S, Pass R. Ocular abnormalities in congenital cytomegalovirus infection. J Am Optom Assoc. 1996; 67(5):273-8

15. Cinti, Sandro. Ocular cytomegalovirus infection: a challenging diagnosis. J Neuroophthalmol. 2008; 28(2):91-2. doi: 10.1097/ WNO.0b013e31817728da

16. Jin H, Demmler-Harrison G, Miller J, Edmond J, Coats D, Paysse E et al. Cortical visual impairment in congenital cytomegalovirus infection. J Pediatr Ophthalmol Strabismus. 2019; 56(3):194-202.

17. Jin HD, Demmler-Harrison GJ, Coats DK, Paysse EA, Bhatt A, Edmond JC et al. Long-term visual and ocular sequelae in patients with congenital cytomegalovirus infection. Pediatr Infect Dis J. 2017 Sep; 36(9):877-82. doi: 10.1097/INF.0000000000001599.

18. Coors LE, Spencer R. Delayed presentation of cytomegalovirus retinitis in an infant with severe congenital cytomegalovirus infection. Retina. 2010 Apr; 30(4 Suppl):S59-62. doi: 10.1097/IAE. 0b013e3181c7018d.

19. Kimberlin D, Jester P, Sánchez P, Ahmed A, Arav-Boger R, Michaels $\mathrm{M}$ et al. Valganciclovir for symptomatic congenital cytomegalovirus disease. N Engl J Med. 2015; 372(10):933-43.

20. Boss JD, Rosenberg K, Shah R. Dual intravitreal injections with foscarnet and ganciclovir for ganciclovir-resistant recurrent cytomegalovirus retinitis in a congenitally infected infant. J Pediatr Ophthalmol Strabismus. 2016 Oct 22; 53:e58-e60. doi: 10.3928/ 01913913-20161003-02.
21. Leung AK, Sauve RS, Davies HD. Congenital cytomegalovirus infection. J Natl Med Assoc. 2003 Mar; 95(3):213-8.

22. Bouthry E, Picone O, Hamdi G, Grangeot-Keros L, Ayoubi J, Vauloup-Fellous C. Rubella and pregnancy: diagnosis, management and outcomes. Prenat Diagn. 2014; 34(13):1246-53.

23. Tecson J, Santiago A. Profile of childhood cataract cases at the Philippine General Hospital. Philip J Ophthalmol. 2004; 29(3):140-3.

24. Li L, Wang Y, Xue C. Effect of timing of initial cataract surgery, compliance to amblyopia therapy on outcomes of secondary intraocular lens implantation in chinese children: a retrospective case series. J Ophthalmol. 2018; 2018:1-7.

25. Hariharan U, Garg R, Nagpal V, Pawar M. Combined cardiac and noncardiac surgery in an infant with congenital rubella syndrome: an anesthetic challenge. Pediatr Anesth. 2011; 21(11):1168-9.

26. Cheschim M, Candiotti K. Airway Management In Highly Infectious Diseases: The Reemergence of Measles [Internet]. 2020 [cited 9 April 2021]. Available from: https://www.anesthesiologynews.com/ReviewArticles/Article/08-19/Airway-Management-In-Highly-InfectiousDiseases-The-Reemergence-of-Measles/55660?sub=AC4CECF6125 6FD5A915AAA437BE2D2CBBE67C9106EDDDFCBB5B2C79B 7DE661\&enl=true\&dgid=\&utm_source=enl\&utm_content=1\&utm_ campaign $=20190823 \&$ utm_medium $=$ button

27. Dewan L, Hasan N, Aron N, Chawla R, Sundar D. Rubella retinopathy with choroidal neovascular membrane in a 7-year-old. Indian $\mathrm{J}$ Ophthalmol. 2020; 68:1176-7.

28. Veloso C, Costa R, Oréfice J, Oréfice F. Spontaneous involution of choroidal neovascularization secondary to rubella retinopathy. Eye. 2007; 21:1429-30. doi: 10.1038/sj.eye.6702940

29. American Academy of Pediatrics. Year 2007 Position Statement: Principles and Guidelines for Early Hearing Detection and Intervention Programs. Pediatrics. 2007; 120(4):898-921.

\section{The Acta Medica Philippina is now accepting limited advertising for its front and back cover (colored), as well as for available spaces in some of its pages, as appropriate. For inquiries and submission of proposals, please email us at actamedicaphilippina.upm@up.edu.ph}

